ACTA UNIVERSITATIS WRATISLAVIENSIS

No 3978

PRZEGLĄD PRAWA I ADMINISTRACJI CXX/1

WROCŁAW 2020

https://doi.org/10.19195/0137-1134.120.14

\title{
MARTA KŁOPOCKA-JASIŃSKA
}

ORCID: 0000-0001-9205-4353

Uniwersytet Wrocławski

Katedra Prawa Konstytucyjnego

\section{KILKA UWAG O POSZERZANIU ZAKRESU MERYTORYCZNYCH KOMPETENCJI SĄDÓW ADMINISTRACYJNYCH W ŚWIETLE ART. 184 KONSTYTUCJI I KONSTYTUCYJNEJ ZASADY PODZIAŁU WŁADZ}

\begin{abstract}
Abstrakt: Przedmiotem artykułu jest zagadnienie możliwości poszerzania zakresu kompetencji sądów administracyjnych do merytorycznego orzekania, analizowane w świetle regulacji konstytucyjnej. Przeciwko wyposażeniu sądów administracyjnych w kompetencje do rozstrzygania spraw administracyjnych w szerszym niż dotychczas zakresie podnoszone są argumenty, że jest to niezgodne z konstytucyjnym pojęciem „kontroli” zawartym w art. 184 Konstytucji oraz konstytucyjną zasadą podziału władz. Analizując te kwestie, autorka prezentuje stanowisko odmienne, wskazując, że art. 184 Konstytucji nie można rozpatrywać w oderwaniu od art. 45 ustawy zasadniczej i przewidzianych tam gwarancji, co wpływa na sposób jego interpretacji. Z kolei odnosząc się do zasady podziału władz, uważa, że należy uwzględniać jej cel, którym jest przede wszystkim ochrona praw człowieka, oraz odwołać się do wartości konstytucyjnych, takich jak zapewnienie rzetelności i sprawności działaniu instytucji publicznych.
\end{abstract}

Słowa kluczowe: sądownictwo administracyjne, kontrola działalności administracji publicznej, zasada podziału władz, merytoryczne orzekanie przez sądy administracyjne, reformatoryjny model orzekania, konstytucyjne prawo do sądu

Interesującym zagadnieniem dotyczącym sądownictwa administracyjnego jest zakres jego kompetencji z punktu widzenia regulacji konstytucyjnej, zwłaszcza art. 184 i art. 10 Konstytucji RP ${ }^{1}$. W szczególności chodzi tutaj o możliwość udzielenia sądom administracyjnym kompetencji do merytorycznego orzekania w powierzonych im do rozpoznania sprawach ${ }^{2}$.

${ }^{1}$ Konstytucja Rzeczypospolitej Polskiej z dnia 2 kwietnia 1997 roku (Dz.U. Nr 78, poz. 483).

2 Posługuję się tutaj sformułowaniem użytym w tytule artykułu Z. Kmieciaka, Merytoryczne orzekanie przez sądy administracyjne $w$ świetle konstytucyjnej zasady podziału władz, „Przegląd Legislacyjny" 2015, nr 2, s. 9. 
Tematu „głębokości” orzekania w sprawach objętych kognicją sądów administracyjnych nie można uznać za nowy ${ }^{3}$. Kwestia ta jest od dawna przedmiotem ożywionej dyskusji naukowej. Była też podnoszona w Komisji Konstytucyjnej Zgromadzenia Narodowego w trakcie prac nad obowiązującą konstytucją ${ }^{4}$. Problem ten zyskał jednak na aktualności w związku z przeprowadzoną w Polsce w 2015 roku reformą prawa o postępowaniu przed sądami administracyjnymi ${ }^{5}$. Na skutek reformy przyznano bowiem sądom administracyjnym kompetencję do określenia w wyroku uwzględniającym skargę sposobu załatwienia sprawy lub sposobu jej rozstrzygnięcia, jeżeli jest to uzasadnione okolicznościami sprawy. Przewidziano też, że w razie niewydania decyzji lub postanowienia przez organ w określonym przez sąd terminie strona może wnieść skargę, żądając wydania orzeczenia stwierdzającego istnienie albo nieistnienie uprawnienia lub obowiązku, a sąd może wydać orzeczenie w tym przedmiocie, jeżeli pozwalają na to okoliczności sprawy.

W uzasadnieniu do projektu ustawy (druk sejmowy nr 1633, VII kadencja Sejmu) przedstawionego przez prezydenta w 2013 roku wskazano, że choć projektowana nowelizacja „,zmierza w kierunku głębszej reformy systemu sądowej kontroli administracji publicznej”, to wprowadzane zmiany nie obejmują miejsca sądownictwa administracyjnego w systemie ustrojowym państwa, które zostało wyznaczone przepisami Konstytucji RP i jest adekwatne do roli sądownictwa administracyjnego w demokratycznym państwie prawa. Podniesiono co prawda, że model orzekania kasacyjnego funkcjonuje dobrze, jednakże w wielu przypadkach dostrzega się potrzebę orzekania merytorycznego, tak aby wpłynąc na przyspieszenie finalnego rozstrzygnięcia w sprawie. $Z$ tego względu zawarte w projekcie propozycje zmian , idą w kierunku merytorycznego orzekania przez sądy administracyjne w ramach wykonywanej kontroli działalności administracji publicznej”, a formuła, w jakiej sądy mają wypełniać funkcję merytorycznego orzekania, zdaniem projektodawcy

nie narusza zasady podziału i równoważenia władz publicznych, sprowadza się bowiem do rozstrzygania sporów o naruszenie lub o realizację praw podmiotowych jednostki. Sądy administracyjne, wydając rozstrzygnięcie w kontradyktoryjnym procesie, nie będą zastępowały władzy wykonawczej w kształtowaniu i wykonywaniu polityki administracyjnej, lecz w ramach sprawowania wymiaru sprawiedliwości będą pełniły rolę gwaranta ochrony i realizacji praw oraz

${ }^{3}$ Warto w tym miejscu wskazać chociażby prace J.S. Landgroda, który postulował stworzenie dwuinstancyjnego sądownictwa administracyjnego o kompetencjach reformatoryjno-kasacyjnych w latach dwudziestych ubiegłego wieku, prezentując odpowiednie projekty ustaw; za: Z. Kmieciak, Postepowanie administracyjne i sq̨dowoadministracyjne a prawo europejskie, Warszawa 2009, s. 157.

${ }^{4}$ Biuletyn KKZN 1995, nr 11, s. 323; Biuletyn KKZN 1996, nr 24, s. 72-73, 77. Zob. M. Wiącek, Art. 184, [w:] Konstytucja RP, t. 2, red. M. Safjan, L. Bosek, Warszawa 2016, s. 1087.

${ }^{5}$ Ustawa z dnia 9 kwietnia 2015 roku o zmianie ustawy — Prawo o postępowaniu przed sądami administracyjnymi (Dz.U. poz. 658). 
wolności jednostki w obszarze wykonywania zadań administracji, zapewniając tym samym konstytucyjne prawo do rzeczywistego dochodzenia naruszonych praw na drodze sądowej.

W uzasadnieniu do projektu wskazano również trzy generalne kierunki zmian. Po pierwsze, projektodawca za cel reformy przyjął usprawnienie, uproszczenie i zapewnienie szybkości postępowania przed sądem administracyjnym, zarówno w pierwszej, jak i drugiej instancji. Mają temu służyć w szczególności zmiany dotyczące zwiększenia zakresu orzekania reformatoryjnego przez NSA (art. 188) oraz wyposażenie wojewódzkiego sądu administracyjnego w uprawnienia merytorycznego orzekania w wypadku kontroli decyzji i postanowień administracyjnych (art. 145a). Po drugie, proponowane zmiany wiążą się z uwzględnieniem ustaleń Trybunału Konstytucyjnego oraz NSA w sprawach związanych z postępowaniem przed sądami administracyjnymi, a po trzecie, zmierzają do wyeliminowania rozbieżności w obecnym orzecznictwie sądowym dotyczącym wykładni przepisów o postępowaniu przed sądami administracyjnymi.

Jak podkreślono, skarżący uruchamiając kontrolę działalności administracji, zainteresowany jest nie tylko najszybszym uzyskaniem orzeczenia sądu administracyjnego, lecz także otrzymaniem zgodnego z prawem rozstrzygnięcia organu administracyjnego, który definitywnie załatwi sprawę administracyjną. Dlatego też zaproponowane rozwiązania, korespondując z postanowieniami art. 6 ust. 1 Konwencji o ochronie praw człowieka i podstawowych wolności oraz z art. 45 Konstytucji, mają w założeniu przyczynić się do ograniczenia negatywnych zjawisk związanych z odwlekaniem w czasie zarówno procesu sądowej kontroli, jak i rozstrzygania spraw administracyjnych.

Kwestia poszerzenia zakresu orzekania sądów administracyjnych w kształcie zaproponowanym w projekcie wywołała jednak spore wątpliwości i nie uzyskała pełnej akceptacji ze strony doktryny. Jeszcze w trakcie trwania procesu legislacyjnego na zlecenie Biura Analiz Sejmowych sporządzone zostały opinie, których autorzy zgłosili swoje wątpliwości co do niektórych rozwiązań proponowanych w projekcie ${ }^{6}$.

Mimo uchwalenia ustawy nowelizującej postępowanie sądowoadministracyjne problem zasadności przydania sądom administracyjnym kompetencji do merytorycznego orzekania nie stracił na znaczeniu. W dniu 27 lipca 2015 roku grupa posłów na Sejm VII kadencji złożyła wniosek do Trybunału Konstytucyjnego o stwierdzenie niezgodności z Konstytucją RP zreformowanych w 2015 roku przepisów art. $145 \S 3$, art. 145a, art. 188 i art. 193 ustawy z dnia 30 sierpnia 2002

${ }^{6}$ Zob. B. Szmulik, Opinia do projektu ustawy o zmianie ustawy - Prawo o postepowaniu przed sądami (druk nr 1633), Warszawa 2013; M. Chmaj, Opinia w przedmiocie zgodności z konstytucja i systemem prawnym art. 145 a przedstawionego przez Prezydenta RP projektu ustawy o zmianie ustawy - Prawo o postępowaniu przed sądami administracyjnymi (druk 1633), Warszawa 2014; por. M. Szydło, Opinia prawna na temat projektu ustawy o zmianie ustawy - Prawo o postępowaniu przed sądami administracyjnymi, „Zeszyty Prawnicze BAS”2013, nr 4, s. 190. 
roku — Prawo o postępowaniu przed sądami administracyjnymi ${ }^{7}$ (dalej: p.p.s.a.), w brzmieniu nadanym przez art. 1 pkt 37 i 38 wspomnianej ustawy reformującej z 9 kwietnia 2015 roku. Wnioskodawcy domagali się uznania zaskarżonych przepisów za niezgodne z art. 10 i 184 Konstytucji w zakresie, w jakim

naruszają zagwarantowaną ustrojową równowagę władzy wykonawczej z władzą sądowniczą, poprzez powstałą na podstawie powyższych przepisów możliwość przekazania kompetencji i uprawnień przynależnych dotychczas wyłącznie organom administracji publicznej, wprost przedstawicielom władzy sądowniczej w postaci sądów administracyjnych, zwłaszcza odnośnie do zadecydowania przez ten rodzaj sądów o umorzeniu postępowania administracyjnego, co natenczas było w wyłącznej gestii organu administracji publicznej prowadzącego postępowanie administracyjne ${ }^{8}$.

W uzasadnieniu wniosku w części dotyczącej zarzutu naruszenia art. 10 Konstytucji RP wnioskodawcy odnieśli się wyłącznie do przepisów art. $145 \S 3$ i art. 145a, wskazując, że wprowadzone nimi zmiany „naruszają istotę uniwersalnego paradygmatu demokratycznego państwa prawa w postaci m.in. zasady podziału i równoważenia się władzy w demokratycznym państwie” oraz „tworzą niebezpieczny precedens niedopuszczalnego przesunięcia wyłącznych uprawnień oraz kompetencji organu administracji publicznej nad władzą sądowniczą". Wnioskodawcy podnieśli również, że choć oczywiste jest, że podzielone pod względem kompetencji władze zawsze będą na siebie oddziaływały, co ma zapewnić ich równowagę, to niedopuszczalne jest przekazanie którejkolwiek z tych kompetencji, należącej docelowo do konkretnej władzy, innej władzy publicznej, która specyfiką i właściwościami nie jest ani przygotowana na jej realizację, ani nie jest odpowiednią instytucjonalnie dla przekazanej kompetencji. Ich zdaniem ustawodawca, zmieniając art. 145 p.p.s.a. poprzez dodanie $\S 3$ oraz wprowadzając art. 145a, pozwolił na przekazanie sądom administracyjnym kompetencji do merytorycznego orzekania w sprawach administracyjnych właściwych wyłącznie organom administracji publicznej. Według wnioskodawców aktualny model sądownictwa administracyjnego skonstruowany jest $\mathrm{w}$ ten sposób, że rolą i zadaniem sądu administracyjnego nigdy nie jest podejmowanie merytorycznych rozstrzygnięć w przedmiocie postępowania administracyjnego. Przyjmują bowiem, że

sąd administracyjny jest usytuowany we władzy sądowniczej jako organ kontrolny, ponieważ ten rodzaj sądu ma za zadanie skontrolować — zgodnie zresztą ze swoim ustawowym przeznaczeniem — działalność organów administracji publicznej. W efekcie sąd administracyjny nie może chociażby dlatego właśnie, że ma stricte kontrolne uprawnienia wobec organów administracji publicznej, podejmować decyzji na wskroś merytorycznych odnośnie do sposobu zakończenia postępowania administracyjnego.

${ }^{7}$ Dz.U. z 2002 r. Nr 153, poz. 1270.

8 Wniosek grupy posłów na Sejm VII Kadencji z dnia 27 lipca 2015 roku, dostępny w aktach sprawy o sygn. K 22/15, http://ipo.trybunal.gov.pl/ipo/Sprawa?cid=1\&dokument=14267\&sprawa=15997 (dostęp: 6.02.2020). 
Tym samym uprawnienie sądu administracyjnego do umorzenia postępowania oznacza w ocenie wnioskodawców wkroczenia sądu bezpośrednio w obszar zastrzeżony jedynie dla działalności organu administracji publicznej. W rezultacie za słuszny przyjmują wniosek, że narzucenie organom administracji publicznej w orzeczeniach sądów administracyjnych konkretnych rozstrzygnięć, między innymi możliwości umorzenia postępowania administracyjnego przez sądy administracyjne zamiast dokonywania tego przez organ administracji publicznej prowadzący indywidualne postępowanie, skutkować będzie tym, że w razie wadliwości orzeczeń sądowych odpowiedzialność, także materialną, za treść rozstrzygnięć będą ponosić organy administracji publicznej. Z kolei zarzut naruszenia przepisu art. 184 Konstytucji RP sprowadzili do twierdzenia, że przepisy art. 188 i 193 p.p.s.a., dotyczące postępowania przed NSA, dają temu sądowi możliwość formułowania treści rozstrzygnięć aktów administracyjnych, co wykracza poza pojęcie kontroli działalności administracji publicznej według kryterium legalności i kasacyjny charakter postępowania przed tym organem.

Sprawa ta nie stała się jednak przedmiotem merytorycznego rozstrzygnięcia Trybunału Konstytucyjnego w związku z zakończeniem VII kadencji Sejmu. Zgodnie z obowiązującą wówczas ustawą z dnia 25 czerwca 2015 roku o Trybunale Konstytucyjnym w sprawach wszczętych na podstawie wniosku grupy posłów lub senatorów zakończenie kadencji Sejmu i Senatu nie wstrzymywało postępowania $\mathrm{w}$ Trybunale. $\mathrm{W}$ takim wypadku postępowanie to $\mathrm{z}$ dniem zakończenia kadencji ulegało zawieszeniu na okres sześciu miesięcy. Jeśli dotychczasowy wniosek uzyskał poparcie odpowiednio pięćdziesięciu posłów lub trzydziestu senatorów kolejnej kadencji Sejmu i Senatu, Trybunał postanawiał o podjęciu zawieszonego postępowania. $\mathrm{W}$ przeciwnym razie zawieszone postępowanie umarzał. W niniejszej sprawie, po bezskutecznym upływie sześciomiesięcznego terminu, w trakcie którego możliwe było podjęcie zawieszonego postępowania, Trybunał wydał postanowienie o jego umorzeniu ${ }^{9}$. Nie można jednak wykluczyć, że wniosek tego rodzaju zostanie złożony ponownie.

Problem poszerzania granic kognicji sądów administracyjnych oraz powierzenia im kompetencji do merytorycznego orzekania w sprawach administracyjnych w niezwykle przystępny i syntetyczny sposób przedstawił Z. Kmieciak na łamach „Przeglądu Legislacyjnego” w 2015 roku $^{10}$. Autor ten zresztą od wielu lat podnosi kwestię konieczności odejścia od dotychczasowego paradygmatu sądownictwa administracyjnego na rzecz zwiększenia kompetencji tych sądów w celu zapewnienia jednostce efektywnej ochrony sądowej w sprawach kontroli działań administracji publicznej ${ }^{11}$. Potrzebę tego rodzaju zmiany Z. Kmieciak uzasadnia między innymi przez odwołanie się do międzynarodowych standardów ochrony

\footnotetext{
${ }^{9}$ Postanowienie TK z dnia 8 czerwca 2016 roku, sygn. K 22/15, OTK ZU A/2016, poz. 38.

${ }^{10}$ Z. Kmieciak, Merytoryczne orzekanie..., s. 9 n.

11 Por. Z. Kmieciak, Postepowanie administracyjne..., s. 157.
} 
praw człowieka, wymogów prawa europejskiego oraz w związku z przeobrażeniami dotychczasowego modelu jurysdykcji w państwach europejskich. Podkreśla również, że kasacyjny typ orzekania właściwie nie występuje nigdzie w czystej postaci, a wprowadzane odstępstwa od niego mają wzmocnić ochronę, której domaga się skarżący, usprawnić postępowanie oraz obniżyć jego koszty ${ }^{12}$.

Stanowisko Z. Kmieciaka nie jest jednak powszechnie podzielane. Krytycznie na temat przeprowadzonej reformy wypowiedział się M. Bogusz, wskazując, że paradygmat kasacyjnego charakteru kompetencji sądownictwa administracyjnego znajduje silne oparcie w zasadzie podziału władzy ${ }^{13}$. Jeszcze przed wejściem w życie proponowanych zmian autor wskazywał, że ewentualne przyznanie sądom administracyjnym kompetencji do załatwiania spraw administracyjnych za organy administracji publicznej prowadziłoby do naruszenia tej zasady ${ }^{14}$. Pisał jednak, że

respektowanie zasady podziału władzy implikowałoby konieczność nadania merytorycznej jurysdykcji sądów administracyjnych charakteru raczej wyjątku aniżeli zasady, z czym wiązałaby się potrzeba zapewnienia sądom administracyjnym pewnego marginesu swobody przy dokonywaniu oceny, czy daną sprawę rozstrzygnąć merytorycznie za administrację publiczną czy też nie ${ }^{15}$.

Z kolei po przeprowadzeniu reformy badacz wyraził nieco bardziej kategoryczne stanowisko, uznając, że więcej argumentów przemawia za uznaniem niekonstytucyjności przepisów art. $145 \S 3$ i 145a p.p.s.a. ${ }^{16}$ Stwierdził też, że przepisy te mogą być skutecznie zakwestionowane z perspektywy przepisu art. 10 Konstytucji ${ }^{17}$, a także budzą zastrzeżenia z perspektywy art. 184 Konstytucji ${ }^{18}$, a nawet w świetle art. 78 Konstytucji $^{19}$. Wadliwości wprowadzonych rozwiązań M. Bogusz upatruje przede wszystkim w:

1. stworzeniu rozwiązań, które pozwalają sądowi administracyjnemu nie tyle eliminować z porządku prawnego wadliwą formę działania administracji publicznej, ile upoważniają sąd do wprowadzenia do tego porządku formy prawidłowej, a wręcz do wykonania kompetencji organu administracji publicznej;

2. nadaniu tym rozwiązaniom charakteru reguły, a nie wyjątku, który ogranicza ich stosowanie jedynie do szczególnie uzasadnionych przypadków;

12 Z. Kmieciak, Merytoryczne orzekanie..., s. 10.

${ }^{13}$ M. Bogusz, Charakter kompetencji sadu administracyjnego a zasada podziatu władzy, „Gdańskie Studia Prawnicze” 31, 2014, s. 28-33; idem, Problem konstytucyjności przepisu art. 145 $\S 3$ i art. 145 a prawa o postępowaniu przed sądami administracyjnymi, „Gdańskie Studia Prawnicze” 36, 2016, nr 2, s. 74-75.

${ }^{14}$ M. Bogusz, Charakter kompetencji..., s. 28-29.

15 Ibidem, s. 33.

${ }^{16}$ M. Bogusz, Problem konstytucyjności..., s. 73.

17 Ibidem, s. 74.

18 Ibidem.

${ }^{19}$ Ibidem, s. 75-76. 
3. pozbawieniu bądź ograniczeniu praw strony postępowania administracyjnego w zakresie możliwości zakwestionowania zapadłego w stosunku do niej rozstrzygnięcia $\mathrm{w}$ administracyjnym toku instancji;

4. niedostosowaniu wprowadzonych zmian do reguł obowiązującego postępowania dowodowego, które w obecnym kształcie jest nieadekwatne do potrzeb merytorycznego rozstrzygania spraw przez sądy administracyjne.

Innego zdania są natomiast W. Piątek i A. Skoczylas, którzy w opublikowanym na początku 2019 roku na łamach czasopisma „Państwo i Prawo” tekście rozważają kwestie dalszej przebudowy modelu sądowej kontroli decyzji administracyjnych ${ }^{20}$. Autorzy odnoszą się do prasowych doniesień na temat niewielkiej liczby spraw, w których sądy administracyjne orzekały reformatoryjnie, i podkreślają, że wprowadzenie nowych mechanizmów opierało się na założeniu, że powinny być one stosowane raczej wyjątkowo ${ }^{21}$. Ich zdaniem dotychczasowa praktyka sądów administracyjnych, choć według mnie jest to zbyt krótki czas na dokonywanie ocen przeprowadzonej reformy, pokazuje, że „nowe” uprawnienia przewidziane w art. $145 \S 3$ i art. 145a p.p.s.a. wykorzystywane są przez sądy administracyjne raczej wyjątkowo. W. Piątek i A. Skoczylas zauważają, że w Polsce już przed wejściem w życie ustawy z 9 kwietnia 2015 roku sądy administracyjne były wyposażone w ograniczone kompetencje do merytorycznego orzekania, a „nowe” instrumenty z art. $145 \S 3 \mathrm{i}$ art. 145a p.p.s.a. jedynie wzbogaciły dotychczasowe uprawnienia tego rodzaju. Konkludują zatem, że obecnie w Polsce mamy — podobny jak w innych państwach europejskich - mieszany model kompetencji orzeczniczych sądów administracyjnych, w którym jednakże przeważają uprawnienia kasacyjne, co w zasadzie przesądza o zgodności tego modelu z art. 184 Konstytucji ${ }^{22}$. Do zmian wprowadzonych do postępowania sądowoadministracyjnego w kwietniu 2015 roku autorzy odnoszą się aprobująco. Wyraźnie przy tym zaznaczają, że ewentualne dalsze poszerzanie uprawnień do merytorycznego orzekania przez polskie sądy administracyjne jest możliwe jedynie po ewentualnej zmianie art. 184 Konstytucji ${ }^{23}$. Twierdzą bowiem, że obecny model orzekania przez polskie sądy administracyjne pozostaje pod silnym wpływem regulacji konstytucyjnej, która stoi na przeszkodzie dalszemu jego poszerzaniu w kierunku wyposażania tych sądów w takie uprawnienia, które umożliwiłyby im proste zastępowanie rozstrzygnięć organów administracji publicznej wyrokami sądowymi ${ }^{24}$.

O ile moja ocena reformy postępowania sądowoadministracyjnego przeprowadzonej w drodze ustawy z 9 kwietnia 2015 roku jest zbieżna z oceną W. Piątka i A. Skoczylasa, to jednak trudno mi zaakceptować pogląd, że dalsza modyfikacja

${ }^{20}$ W. Piątek, A. Skoczylas, Kasacyjny czy merytoryczny model orzekania - kwestia zmiany modelu sadowej kontroli decyzji administracyjnych, „Państwo i Prawo” 2019, nr 1, s. 24 n.

${ }^{21}$ Ibidem, s. 25.

22 Ibidem, s. 33.

${ }^{23}$ Ibidem.

${ }^{24}$ Ibidem, s. 36-37. 
uprawnień orzeczniczych polskich sądów administracyjnych, polegająca na poszerzeniu kompetencji reformatoryjnych, w aktualnych uwarunkowaniach konstytucyjnych nie jest już możliwa. Opowiadam się bowiem za poglądem o zgodności z Konstytucją wprowadzonej zmiany, przyjmując, że mieści się ona w ramach swobody regulacyjnej ustawodawcy. Uważam ponadto, że granice tej swobody powinny wyznaczać takie cele, jak potrzeba zapewnienia jednostce efektywnej $i$ adekwatnej ochrony sądowej $w$ jej relacjach $\mathrm{z}$ administracją.

Należy przy tym podkreślić, że art. 184 Konstytucji powierza sądom administracyjnym sprawowanie kontroli działalności administracji publicznej „,W zakresie określonym w ustawie". Ustawodawca ma zatem prawo ukształtowania zasad tej kontroli. Użyte w tym przepisie pojęcie kontroli powinno być interpretowane w sposób autonomiczny, co uzasadnia możliwość nadawania mu swoistego znaczenia, niekoniecznie pokrywającego się ze znaczeniem, które jest pojęciu kontroli przypisywane na gruncie innych dyscyplin prawa, w tym prawa administracyjnego. W konsekwencji pojęcie kontroli z art. $184 \mathrm{zd}$. 1 Konstytucji należy rozumieć szeroko, w tym sensie, że nie determinuje ono w sposób kategoryczny sposobu jej ukształtowania przez ustawodawcę.

W mojej ocenie przepis art. 184 nie wyklucza również przyznania sądom administracyjnym możliwości rozstrzygania spraw merytorycznie w szerszym niż dotychczas zakresie, choć tego rodzaju zmiana powinna zostać gruntownie przemyślana oraz poprzedzona stosowną analizą zalet i wad obecnie funkcjonujących rozwiązań, a także korzyści i kosztów, które może wywołać ewentualna reforma. W takim wypadku ustawodawca musi brać pod uwagę różne czynniki, w tym obowiązek zapewnienia jednostce dostępu do sądu, sprawnego i rzetelnego postępowania sądowego oraz adekwatnych dla danego typu sprawy instrumentów procesowych. Wybór określonych rozwiązań wymaga również oceny tego, w jakim stopniu istniejący mechanizm ochrony jest efektywny, to znaczy — pozwala skutecznie realizować cele, dla których został ustanowiony. W zasadzie wymaga zatem zbadania, czy organy administracji publicznej stosują się do wyroków sądów administracyjnych.

Jeśli chodzi o przywoływane w piśmiennictwie argumenty natury historycznej dotyczące ukształtowania polskiego sądownictwa administracyjnego w oparciu o tak zwany model weryfikacyjny, ale także odnoszące się do przebiegu prac nad tworzeniem art. 184 Konstytucji, to warto zwrócić uwagę, że po pierwsze model sądownictwa administracyjnego ewoluuje i obecnie nie stanowi on modelu weryfikacyjnego w czystej postaci (ponadto nie należy przedkładać „,czystości" modelu nad potrzebę racjonalizacji istniejących rozwiązań i zapewnienia ich operatywności). Po drugie, analizując znaczenie pojęć konstytucyjnych, należy odwołać się do aksjologii konstytucyjnej oraz zasadniczych celów ustawy zasadniczej ${ }^{25}$. Podzielam w tym wypadku pogląd M. Pacha o liberalnym charakterze

${ }^{25}$ M. Pach, Specyfika wyktadni konstytucji w konstytucyjnym państwie prawa na przykładzie Konstytucji RP z 2 kwietnia 1997 r., [w:] Prawo i polityka w sferze publicznej. Perspektywa we- 
obowiązującej konstytucji, przez który rozumie on swoisty program minimum, polegający na stworzeniu instytucjonalnych gwarancji ochrony jednostki przed zagrożeniami jej wolności, który powinien rzutować na sposób odczytywania jej poszczególnych przepisów. Potrzeba zagwarantowania na zawsze praw obywatelskich oraz zapewnienie rzetelności i sprawności działaniu instytucji publicznych to cele określone w preambule ustawy zasadniczej, z czego ten drugi ma charakter wtórny względem pierwszego ${ }^{26}$. W tym duchu należy interpretować postanowienia konstytucji, szczególnie te, które odnoszą się do instrumentów ochrony praw jednostki.

Zdaję sobie sprawę, że przepis art. 184 Konstytucji ma charakter przepisu ustrojowego, który określa zadania nałożone na sądy administracyjne. Nie można jednak zapominać o podstawowych funkcjach gwarancyjnych przypisanych tego rodzaju sądom jako organom wymiaru sprawiedliwości. Przepisu art. 184 Konstytucji nie powinno się zatem rozpatrywać w oderwaniu od art. 45 Konstytucji i przewidzianych tam gwarancji, lecz raczej dostrzegać silny związek między nimi. Sądy administracyjne, sprawując kontrolę działalności administracji publicznej, czynią to także w ramach systemu środków ochrony prawnej, które ma do swojej dyspozycji jednostka pozostająca w konflikcie $\mathrm{z}$ organem władzy publicznej. Z tej perspektywy dużo łatwiej zaakceptować, że art. 184 Konstytucji nie stoi na przeszkodzie możliwości poszerzenia kompetencji orzeczniczych sądów administracyjnych, jeśli pozwoli to zrealizować cel w postaci zapewnienia pełniejszej ochrony praw i wolności jednostki.

Po trzecie, nie jest chyba niczym zaskakującym, że niektóre z założeń wyjściowych poczynionych przez twórców Konstytucji siłą rzeczy muszą podlegać weryfikacji wraz z upływem lat funkcjonowania określonych rozwiązań i nagromadzonych w tym czasie doświadczeń. Jeśli więc traktować konstytucję jako tak zwaną living constitution, to szczególnie w materii dotyczącej statusu jednostki i instrumentów ochrony jej praw uzasadniona może być zmiana dotychczasowego podejścia, jednak przy poszanowaniu innych zasad i wartości konstytucyjnych. Właściwe wydaje się tutaj dynamiczne podejście do interpretacji pojęć, którymi posługuje się ustawa zasadnicza. Może to stanowić argument, który przekona zwolenników wąskiego $\mathrm{i}$,tradycyjnego" rozumienia terminu „kontrola” $\mathrm{z}$ art. 184 Konstytucji.

Zagadnienie poszerzenia kognicji sądów administracyjnych rozpatrywane jest również w świetle konstytucyjnej zasady podziału władzy, nie wydaje się jednak, by z tej perspektywy powierzenie sądom administracyjnym rozstrzygania spraw administracyjnych, które nie zostały należycie rozpoznane przez organ administracji, byłoby czymś zupełnie odmiennym od rozstrzygania spraw przez sądy powszechne rozpoznające sprawy z zakresu działania administracji czy weryfiku-

wnętrzna, red. P. Jabłoński, J. Kaczor, M. Pichlak, Wrocław 2017, s. 19, http://repozytorium.uni. wroc.pl/Content/89891/01_01_M_Pach_Specyfika_wykladni_konstytucji.pdf.

26 Ibidem. 
jące prawidłowość decyzji wydanych przez inne organy, co nie było dotychczas kwestionowane w świetle omawianej zasady ustrojowej. Należy też zwrócić uwagę na podstawowy cel tej zasady, którym jest ochrona praw człowieka, którego to celu nie powinno się lekceważyć w dyskusji nad reformą wymiaru sprawiedliwości, w tym o poszerzaniu kompetencji sądów administracyjnych.

Ponadto, skoro za inne cele zasady podziału władzy uznaje się także skłonienie organów podzielonej władzy do harmonijnej współpracy, zapewnienie sprawnego i racjonalnego funkcjonowania państwa oraz stworzenie mechanizmu integrującego działania poszczególnych segmentów aparatu państwowego, to wydaje się, że rozwiązania, które tym celom służą, raczej mogą sprzyjać realizacji tej zasady. Nie zakładałabym zatem a prori, że poszerzenie kompetencji do merytorycznego orzekania przez sądy administracyjne w szerszym, niż to ma miejsce obecnie, zakresie pozostaje w sprzeczności z art. 10 Konstytucji. W systemach, w których występuje reformatoryjny model orzekania, nie chodzi przecież o to, aby sądy administracyjne przejęły kompetencje administracji publicznej, ale o to, by mogły interweniować w razie jej błędnych posunięć, a gdy jest to uzasadnione, jej działania korygować. Nie uważam, by reagując na nieprawidłowości w działaniu organów administracji publicznej bądź rozstrzygając konflikty powstałe w związku z tym działaniem i doprowadzając do stanu pożądanego z perspektywy ochrony jednostki oraz na jej wniosek, sądy działały wbrew zasadom wynikającym z art. 10 Konstytucji. Nie rozpatrywałabym koniecznie takiego działania sądów w kategoriach naruszania ,istoty” władzy wykonawczej, lecz raczej jako wypełnianie przypisanej im konstytucyjnie roli organów stojących na straży praw i wolności jednostki i praworządności. To z kolei powinno prowadzić do pełniejszej realizacji celów zasady podziału i równowagi władzy, w tym dążenia do usprawnienia i racjonalizacji działań państwa. Zwłaszcza że stopniowa ewolucja modelu kasacyjnego w kierunku poszerzania kompetencji sądów administracyjnych do merytorycznego orzekania wynikła przecież z jego niedostatków i była podyktowana potrzebą zwiększenia jego efektywności ${ }^{27}$.

\author{
REMARKS ON ADJUDICATION ON THE MERITS BY
}

ADMINISTRATIVE COURTS IN THE LIGHT OF ARTICLE 184 OF THE CONSTITUTION AND CONSTITUTIONAL PRINCIPLE OF SEPARATION OF POWERS

\author{
Summary
}

The subject of the article is the issue of possibly broadening the scope of competence of administrative courts for adjudication on the merits, analysed in the light of constitutional regulations.

${ }^{27}$ Zob. W. Piątek, A. Skoczylas, Kasacyjny czy merytoryczny model orzekania..., s. 27 i cytowana tam literatura; M. Kowalski, Prawo do sądu administracyjnego. Standard międzynarodowy i konstytucyjny oraz jego realizacja, Warszawa 2019, s. 175, 295, 457, 460. 
Against equipping administrative courts with the competence to resolve administrative cases in a wider scope than before, arguments are raised that it is inconsistent with the constitutional notion of „control" contained in Article 184 of the Constitution and the constitutional principle of separation of powers. Analysing the above issues, the author presents a different position indicating that Article 184 of the Constitution cannot be considered in isolation from Article 45 of the Constitution and the guarantees provided therein, which affects the way it is interpreted. In turn, referring to the principle of separation of powers, it is proposed that its aim, which is primarily to protect human rights, should be taken into account and reference should be made to constitutional values such as ensuring the reliability and efficiency of public institutions.

Keywords: administrative judiciary, control of public administration activities, the principle of separation of powers, adjudication on the merits by administrative courts, reformatory powers of administrative courts, constitutional right of access to a court

\section{BIBLIOGRAFIA}

Bogusz M., Charakter kompetencji sądu administracyjnego a zasada podziału władzy, „Gdańskie Studia Prawnicze" 31, 2014.

Bogusz M., Problem konstytucyjności przepisu art. 145 \& 3 i art. 145 a prawa o postępowaniu przed sądami administracyjnymi, „Gdańskie Studia Prawnicze” 36, 2016, nr 2.

Chmaj M., Opinia w przedmiocie zgodności z konstytucja i systemem prawnym art. 145 a przedstawionego przez Prezydenta RP projektu ustawy o zmianie ustawy - Prawo o postępowaniu przed sądami administracyjnymi (druk 1633), Warszawa 2014.

Kmieciak Z., Merytoryczne orzekanie przez sady administracyjne $w$ świetle konstytucyjnej zasady podziału władz, „Przegląd Legislacyjny” 2015, nr 2.

Kmieciak Z., Postepowanie administracyjne i sadowoadministracyjne a prawo europejskie, Warszawa 2009.

Kowalski M., Prawo do sądu administracyjnego. Standard międzynarodowy i konstytucyjny oraz jego realizacja, Warszawa 2019.

Pach M., Specyfika wyktadni konstytucji w konstytucyjnym państwie prawa na przyktadzie Konstytucji RP z 2 kwietnia 1997 r., [w:] Prawo i polityka w sferze publicznej. Perspektywa wewnętrzna, red. P. Jabłoński, J. Kaczor, M. Pichlak, Wrocław 2017.

Piątek W., Skoczylas A., Kasacyjny czy merytoryczny model orzekania — kwestia zmiany modelu sadowej kontroli decyzji administracyjnych, „Państwo i Prawo” 2019, nr 1.

Szmulik B., Opinia do projektu ustawy o zmianie ustawy - Prawo o postępowaniu przed sadami (druk nr 1633), Warszawa 2013.

Szydło M., Opinia prawna na temat projektu ustawy o zmianie ustawy - Prawo o postępowaniu przed sadami administracyjnymi, „Zeszyty Prawnicze BAS” 2013, nr 4.

Wiącek M., Art. 184, [w:] Konstytucja RP, t. 2, red. M. Safjan, L. Bosek, Warszawa 2016.

Przegląd Prawa i Administracji CXX, 2020, cz. 1 i 2

(C) for this edition by CNS 